\title{
Migration, Trade, and Foreign Direct Investment in Mexico*
}

\author{
Patricio Aroca Gonzalez \\ Universidad Católica del Norte, Antofagasta, Chile \\ William F. Maloney \\ Office of the Chief Economist for Latin America \\ The World Bank
}

\begin{abstract}
Part of the rationale for NAFTA was that it would increase trade and foreign direct investment (FDI) flows, creating jobs and reducing migration to the U.S. Since poor data on illegal flows to the U.S. make direct measurement difficult, this paper instead evaluates the mechanism behind these predictions using data on migration within Mexico where the census data permit careful analysis. We offer the first specifications for migration within Mexico incorporating measures of cost of living, amenities and networks. Contrary to much of the literature, labor market variables enter very significantly and as predicted once we control for possible credit constraint effects. Greater exposure to FDI and trade deters out-migration with the effects working partly through the labor market. Finally, we generate some tentative inferences about the impact on increased FDI on Mexico-U.S. migration. On average, a doubling of FDI inflows leads to a $1.5-2 \%$ fall in migration.
\end{abstract}

\begin{abstract}
World Bank Policy Research Working Paper 3601, May 2005
The Policy Research Working Paper Series disseminates the findings of work in progress to encourage the exchange of ideas about development issues. An objective of the series is to get the findings out quickly, even if the presentations are less than fully polished. The papers carry the names of the authors and should be cited accordingly. The findings, interpretations, and conclusions expressed in this paper are entirely those of the authors. They do not necessarily represent the view of the World Bank, its Executive Directors, or the countries they represent. Policy Research Working Papers are available online at http://econ.worldbank.org.
\end{abstract}

\footnotetext{
* This paper was financed by the regional studies program of the Office of the Chief Economist for Latin America at the World Bank. Our thanks to Gordon Hanson and Raymond Robertson for insightful comments and Gabriel Montes Rojas and Lucas Siga for expert research assistance.
} 
"Mexico wants to export goods, not people."

Carlos Salinas de Gortari

\section{Introduction}

Mexican President Carlos Salinas de Gortari promoted the North American Free Trade Agreement (NAFTA) partly on the grounds that it would reduce the incentives for Mexicans to migrate north. While intuitively appealing, several literatures have suggested possible slips 'twixt cup and lip. First, Razin and Sadka (1997) note that dropping the assumption of identical production technologies or permitting increasing returns to scale allows trade and migration to be complements rather than substitutes. ${ }^{1}$ Second, Markusen and Zahniser (1999), drawing on models and empirical evidence by Feenstra and Hanson (1995) and Markusen and Venables (1995) suggest that the foreign direct investment (FDI) and trade effects of NAFTA are likely to increase the relative earnings of skilled workers but not those of unskilled workers who are most likely to migrate. Third, much of the migration literature has failed to find a significant or intuitive impact on migration of initial location wages or unemployment rates (Greenwood 1997, Lucas 1997), casting some doubt on how strong any trade or FDI effects working through the home country labor market would be. Fourth, and more worrisome, there is increasing evidence that liquidity constraints pose a barrier to migration- it takes resources to move (see Stark and Taylor 1991). If FDI or trade flows relax this constraint, the expected substitution effect may be partially or completely offset, leading to greater migration (See López and Schiff 1998).

The illicit nature of Mexican-US migration flows means they are poorly measured and this forces us to rely on indirect approaches to the question. A small detailed case study literature on individual municipalities offers some suggestive evidence that the NAFTA related phenomena-- female manufacturing employment and proximity to a

\footnotetext{
1 More generally, Faini (2004) notes the complex feedbacks among trade, FDI and migration that can obscure the final impact of liberalizing one sector on migration.
} 
maquila-- might reduce migration. ${ }^{2}$ In a times series context, Hanson and Spillimbergo (1999) find that border apprehensions are responsive to US-Mexico wage differentials, a finding confirmed by McKenzie and Rapoport (2003) using a retrospective survey. Davila and Saenz (1990) find a negative relationship between lagged maquila employment on the border and monthly border apprehensions as a proxy for migration pressures. Unfortunately, more direct trade data on FDI and trade are available neither at the level of periodicity or span to offer enough degrees of freedom to permit inference with any confidence. Further, the massive peso crisis beginning roughly concomitant with the signing of NAFTA led to a sharp spike in unemployment and a $25 \%$ fall in wages. These likely induced flows to the US that complicate inference on the more modest effects that NAFTA might have had in the opposite direction.

For these reasons, this paper focuses on evaluating the mechanisms through which NAFTA related variables might work using data on migration flows within Mexico where the 2000 census data permit careful analysis and the 32 by 32 permutations offer substantial degrees of freedom. Figure 1 shows the rates of net migration (net flows as a fraction of the population in the initial period) by state and figure 2 FDI by state. A casual look suggests that, in fact, there is a relationship between the magnitude of FDI and migration to a bcale. In investigating this possibility for FDI and other trade variables more rigorously, we make three contributions to the literature on migration more generally, and then specifically on the impact of trade and FDI flows on migration.

First, we offer the first estimates of determinants of migration flows within Mexico and make some advances in the less developed country (LDC) migration literature. In line with recent innovations in the industrialized country literature, we generate proxies for both the level of amenities and costs of living and find their influence to be statistically significant. Further, contrary to much of the literature either in the industrialized or developing world noted above, our specification allows

\footnotetext{
2 Using data gathered in 25 Mexican communities, Massey and Espinosa (1997) create histories of migrants to the US and find initial migration to the US to be negatively related to the wage rate and the proportion of women in manufacturing. Jones (2000) examines 17 emigrant municipalities and argues in favor of an association between proximity to maquiladoras and employment growth and, in turn, declining US migration.
} 
disentangling relative expected earnings effects from the liquidity effect, and we find very significant and very intuitively plausible signs on labor market variables. Finally, we introduce networking effects and find them also strongly significant.

Second, we document that both FDI and trade variables are substitutes for labor flows, are likely to work through the labor market, and have substantial deterrent effects. Even without the application to international migration, this finding is of intrinsic interest in the context of the literature working at the nexus of national spatial income disparities and migration (Barro and Sala i Martin 1992, Gabriel, Shack-Marquez and Wascher 1993, Esquivel 1997) and the literature on how trade liberalization may affect regional disparities (Hanson 1997, Aroca, Bosch, Maloney 2000). However, by establishing that the mechanisms through which NAFTA was to impact migration indeed function at the domestic level, we offer support for President Salinas' claim for international migration as well. Further, we implicitly address Markusen and Zahniser's concern that the skills demanded by FDI and trade are higher than those possessed by the majority of migrants to the US and hence that NAFTA may have no effect.

Finally we generate some tentative "back of the envelope" inferences about the impact on Mexico-US migration treating the US implicitly as the $33^{\text {rd }}$ Mexican state. We find the impacts to be of important magnitude.

\section{Methodology}

We assume that the potential migrant faces $\mathrm{j}$ possible destinations where $\mathrm{i}$ is the region of origin and $\mathrm{k}$ is the migration region chosen. The worker's internal migration decision is reflected by the sign of the index function

$$
I^{*}=V_{k}-V_{i}-C
$$

where $V$ can be interpreted as an indirect utility function in the context of random utility theory (Domencich and McFadden, 1975 and Train, 1986), and C is a measure of costs. We assume that utility is a function of a linear combination of location characteristics $\mathrm{X}$ 


$$
V_{j}=X_{j} \beta+e_{j}
$$

If the destination region is more desirable, measured along several dimensions, and if the migrant has sufficient resources to move, then we should observe migration. The probability that the indicator will be larger than zero is equal to the probability that the difference between V's is greater than transport costs:

$$
P\left(I^{*}>0\right)=P\left(V_{k}-V_{i}-C>0\right)=P\left(\varepsilon_{i}-\varepsilon_{k} \leq X_{k} \beta-X_{i} \beta-C\right)
$$

This specification nests many standard estimated functions (see Greenwood 1997) including Borjas' (2001) where the only argument in the utility function is the wage. ${ }^{3}$ The actual specification depends on the assumptions about the error term.

The $\beta$ s may be allowed to vary and in fact the literature tends to find a greater role for destination variables than for origin variables. This may be because of asymmetric information about locales (Gabriel et.al 1993), or because the individual variables are correlated with omitted variables that may have a greater impact on one end of the migration move. As an example that we discuss in more detail later, many variables could be correlated with unmeasured wealth or liquidity that would determine whether the worker has the savings to pay the fixed $\operatorname{cost} \mathrm{C}$ of moving.

The matrix $X$ contains the variables capturing the relative expected incomes (Y) in the two areas (wages, unemployment, price indices), and the set of characteristics of the region (amenities) that may also affect the migration decision. It is through $\mathrm{Y}$ that we might expect the impact of FDI and trade.

Since we work with aggregate data, we follow Ben-Akiva and Lerman (1985) as generalized in Gourieroux (2000). Here

\footnotetext{
${ }^{3}$ Borjas argues that $I^{*}=\max _{j}\left\{w_{j}\right\}-w_{i}-C$ where $I^{*}$ is an indicator variable, $w$ is the wage and $C$ the costs of transportation to the new locale. This function must satisfy $w_{k}=\max _{j}\left\{w_{j}\right\}$, where $j$ represents all possible destinations, $i$ the region of origin and $k$ the region chosen.
} 


$$
F^{-1}\left(P\left(I^{*}>0\right)\right)=X_{k} \beta_{d}-X_{i} \beta_{o}-C
$$

where $\mathrm{F}$ is the probability function that is determined by the structure of the errors.

The overall approach is to estimate a broadly standard specification augmented with some additional proxies and modified to better capture liquidity effects. We then introduce integration related variables and explore to what degree their effects are channeled through the labor market.

\section{Data}

Migration data: The 2000 census generates migration flows from a question that asks in what state the interviewee resided 5 years ago. Though this approach is standard in the literature, it has the drawback of obscuring migrants who may have left and returned in the five year period. Flows to the US are derived from a question asking whether during the last five years a member of the household has gone to the US.

Moving Costs: Following the literature (again, see Greenwood 1997), we approximate the costs of transportation as a quadratic function of distance. ${ }^{4}$ This is a proxy for the costs of migration that consist of the moving costs themselves, the opportunity costs of moving which rise with the length of the journey, and rising communication costs with the family in the point of origin, including the increased costs of return visits. In general, the literature expects a negative impact on migration but with decreasing effect.

Networks: An emerging literature stresses the importance of existing networks as lowering transaction and information costs. The Mexico-US literature has particularly expanded on this point (see, Zabin and Hughes 1995, Massey and Espinosa 1997, Winters, de Janvry and Sadoulet 2000, McKenzie and Ropoport 2004 among others).

4 Though we assume that the indirect utility function is linear and the weight of each variable is similar in each region, this assumption can be easy relaxed to differentiate the origin (o) and destination (d) parameters. 
Following the literature on within country migration, we use the share of the population that had arrived in destination $\mathrm{j}$ more than 5 years ago that was born in state of origin $\mathrm{i}$ as a proxy.

Population: is the population by state in 1995 as reported by the Census. As Greenwood (1997) summarizes, population is often used as a measure of the availability of public goods. However, it is also true that larger states offer more "connection points" than small states and will hence, in a random reallocation, attract more migrants. Shultz (1982) is also correct in arguing that larger states may have smaller rates of out migration simply by virtue of having more places to migrate to within. The 1995 value is used to eliminate any problems of simultaneity with migration flows that happen in subsequent years.

Labor Market Variables: The unemployment and nominal wage variables are generated as the average of their quarterly values in 1995, 1996 and 1997 from the National Urban Employment Survey (Encuesta Nacional de Empleo Urbano- ENEU).

Cost of Living: Though presumably the potential migrant should be focusing on real as opposed to nominal expected wages, the actual deflator used may not be that of the current place of work. For instance, if a migrant plans to return to a low cost area to retire, he may generate real savings measured in his retirement destination faster by earning a lower real wage in a high cost area (See Lucas 1997 for a survey of this literature). Further, high cost of living may point to a larger potential income over the long run even if not experienced even by the individual making the decision (Spencer 1989, Pagano 1990). Certainly, in an intertemporal or intergenerational context, taking a lower real wage in the US is still likely to offer the migrant's descendents far better options than would have been the case in Mexico. ${ }^{5}$

\footnotetext{
5 The literature provides mixed evidence. Cameron and Muellbauer (1997) studying UK migration find strong "deflator" effects that they argue dominate any expectation effects. On the other hand, Thomas (1993), also looking at the UK, finds no impact of regional house price difference on destination choice of any group except retirees.
} 
The existing price indexes for Mexican states do not allow comparisons of cost of living across states. For this reason we create two indices using the ending module of the National Survey of Household Income and Spending (ENIGH 1992/8 Encuesta Nacional de Ingresos y Gastos de los Hogares). Since food likely comprises a larger share of the consumption basket in LDCs, ${ }^{6}$ we generate a Laspeyres Index of a consumption basket of 200 items where the price and basket of reference are the national average in 1992. The housing price index was created using hedonic prices for rented houses only and is analogous to those used in the industrial country literature. Housing characteristics include number of rooms; kitchen; bathroom; electricity; telephone; water drainage and potable water; and type of walls, floors and ceilings and community size. Both indexes were included separately and as an average measure of the cost of living and were included free standing to allow for the effects described above. The most satisfactory results were gained with an average measure and these we report.

Amenities: Price indices, however, may also simply reflect amenities available in the new area, implying a positive relation with migration decisions. Further, as Roback (1982) showed, they affect equilibrium wages as well and hence should be included as part of the net utility change of moving from one region to another. A measure of amenities across Mexican states was created by the National Institute of Economic and Geographical Information using the 2000 General Census of Population and Housing. However, it includes measures of labor market tightness as well as migration variables (percentage of resident population who were born in other states and percentage residing in other states), variables whose influence we are trying to separate out. We therefore create a new index incorporating information on the percentage of the population living in urban areas, mortality rates, health infrastructure (number of nurses per capita, doctors per capita, hospitals per capita, beds) education (students per teacher in primary, secondary schools), and infrastructure (percentage and education of houses with electricity and without water drainage). We identified fur significant factor loadings

6 The ENIGH gives information on expenses for all items, but only unit price and quantity consumed for food items. Nevertheless the survey also includes House Characteristics which allow us to estimate also Housing. 
with the first having the strongest interpretation as capturing amenities. The correlation with wages for this measure is 0.37 , while the correlation with the INEGI's welfare index is 0.77 .

\section{Trade and Investment Variables}

Foreign Direct Investment: This is aggregate per capita foreign direct investment from 1995-1999 reported to the government by the firms investing and was provided by the Central Bank of Mexico. The Federal District (DF)- Mexico City- shows vastly higher rates because much of the FDI destined for other states is registered at the headquarters of the firm in the DF. We include a dummy variable in the regressions to account for this measurement error. As figure 2 suggests, FDI is highly, although not exclusively concentrated along the northern border with the US.

Maquila Value Added: This variable may be seen purely as a proxy for FDI, but since the maquilas are primarily exporters, it can also be seen as a proxy for "maquila exports per capita" which brings it closer to being a trade variable. Since it is collected from industrial surveys, it does not suffer from the "headquarters" effect of the FDI variable. The two variables are moderately correlated (.64) and hence are it may be a serviceable proxy for FDI more generally. On the other hand, the government of Mexico tabulates 12 of the states in an "other" category and the loss of these state implies reduced information and potential selection bias. We run the regressions with the substantially reduced sample.

Exports: This variable is provided by the Ministry of Finance (MOF). As with the FDI data, the exports reported by firm are assigned to the location of the headquarters, often in the DF, which may not be the actual location of production. The MOF therefore reassigns the firm's aggregate exports proportionally using data on the location of plants and employees of each firm found in the Mexican Institute of Social Security (IMSS) data base. The methodology does not include oil or electricity exports and may miss smaller firms which do not register with IMSS. 
Imports: This variable could have multiple and conflicting effects. It could simply reflect the degree of integration of a state with external economies and hence proxy as well for exports. On the other hand, if it is seen as representing competition for import substituting firms, the short run labor market impact could be negative and hence it could conceivably lead to more migration. The data were provided by Bancomex.

None of the variables are ideal, but they are complementary in the sense of being strong whether the other is weak. Together, we may get a reliable picture of the impact of trade/investment variables.

\section{Results}

In preliminary regressions, we estimated a multinomial logit model for aggregate data. Though the results were plausible, the Fry and Harris test (1998) suggests that the data violate the Independence of Irrelevant Alternatives (IIA). Therefore, we estimate a multinomial probit and follow Gourieroux's (2000) weighted least square procedure.

Columns 1a and $\mathrm{lb}$ (Table 2), present the standard regression including the labor market variables. Across the next columns, the various FDI and trade variables are added. Overall, the specifications are very satisfactory with the coefficients on the core variables generally statistically significant and of predicted sign. The costs of movement measures -distance and network- are significant in all specifications and, in the former case are well within the usual range found in the literature (Greenwood 1997, see also Gabriel et al 1996, Fields 1982, and Schultz, 1982). The population of the destination enters significantly and of positive sign in all specifications consistent with either a "connection point" interpretation, a residuals amenity effect, or perhaps congestion externalities. The coefficient on the origin is unstable across specifications. 
The cost of living variable enters very significantly and of important magnitude in the sector of origin. The strong positive coefficient on the destination is unexpected. It may perhaps be consistent with the view of cost of living being a measure of expectations for future income growth as discussed earlier. Alternatively, as with many of the explanatory covariates, the cost of living is likely to be endogenous to immigration flowsgrowing population pushing up the cost of housing, goods and services- and hence potentially biased. However, the lack of credible instruments precludes a serious attempt to deal with simultaneity bias so we simply leave this as a caveat.

There appears to be some interaction between the amenities and networking variables. In the absence of the latter, the amenities variable enters with predicted signs, but again in the relative/free standing format that suggests that amenities may be correlated with an omitted credit constraint variable. Including networking reduces the significance of the relative amenities term in virtually all specifications. The reason is not clear although it may be that the cumulative migration from origin to destination of the past that is the networking term is especially related to the relative amenities levels.

\section{Labor Market Variables}

Preliminary estimations of $1 \mathrm{a}$ and $1 \mathrm{~b}$ found both the origin unemployment and wage level to be insignificant as has been found frequently in the literature (Greenwood 1997, Lucas 1997). However, we then attempted to isolate two countervailing effects, one a substitution effect among states, and the other a wealth or liquidity effect that allows the worker to cover the fixed cost of moving. The latter effect has been found for unemployment by Goss and Schoening (1984) and Herzog et al. (1993) for the US; they find that the probability of moving decreases with the duration of unemployment. The literature on the wage effect is also extensive (See Stark and Taylor 1991 for a discussion of credit constraints). We generate relative wage (ln wj-ln wi) and relative unemployment $(\mathrm{Uj} / \mathrm{Ui})$ variables to capture substitution effects and the n allow free standing initial wage and unemployment variables to capture credit constraint effects. In the complete sample, all but the free standing unemployment term enter significantly although it is of predicted 
sign and significant at the $10 \%$ level in the restricted regression. This overall strong performance suggests that the poor results of home labor market variables in many previous studies arises precisely because they capture two contradictory tendencies.

\section{Integration Variables}

Columns 2a, 3a, 4a and 5a drop the labor force variables and replace them with the trade and investment variables, again in relative and free standing form. In all cases, we find evidence of a strong substitution effect: FDI and trade reduce migration. The free standing term was significant in half the cases consistent with López and Schiff's (1998) concern that trade and investment integration may plausibly increase migration flows by releasing liquidity/wealth constraints. In the case of maquilas and imports, it appears that this liquidity effect offsets to some extent the substitution effect found in the relative term. ${ }^{7}$

Columns $2 \mathrm{~b}, 3 \mathrm{~b}, 4 \mathrm{~b}$, and $5 \mathrm{~b}$ add the labor force variables and suggest that some, but not all of the effect of the trade and investment variables works through the labor market. This is consistent with Hanson's (2005) finding that the distribution of conditional labor income in states highly exposed to very similar trade and investment variables were shifted to the right relative to states with low exposure. The substitution effect diminishes by at least a factor of 2 in most cases and in the case of FDI becomes insignificant. The exception is the maquila variable, which appears to strengthen. Whether this is due to the selection bias caused by the authorities grouping states with small maquila presence is not clear.

\footnotetext{
${ }^{7}$ As additional robustness tests, we ran two additional variants of the base and FDI regressions. We first include a full set of state dummies, both origin and destination. This had the predictable effects of the substantially reduced degrees of freedom, but had relatively little effect on the magnitudes of the core variables. In the key specification on which we base our simulations, $2 \mathrm{~b}$, the relative FDI term changed little, falling from .029 to .021 and the $\mathrm{t}$ from 6.4 to 3.6. The free standing term remained insignificant. Second, we include a measure of relative education levels measured as average years of schooling. The relative and free standing initial terms enter insignificantly and had little impact on the other covariates with the exception of a perhaps predictably lowering, somewhat, of the relative wage term and rendering insignificant the free standing amenities term.
} 
The free standing terms trade and investment variables also show propensity to flip sign in all cases suggesting that they were capturing the initial wealth/liquidity now captured by initial wages and unemployment. Minus this effect the trade and investment variables have a more powerful deterrent effect than destination an attractive effect. The fact that all relative trade and investment variables retain an effect outside of the contemporaneous labor market variables may reflect that there is an independent disincentive effect to migrate, perhaps through expectations of future growth. In all cases, the possible endogeneity between local labor market variables and the location of trade/FDI is left largely unexplored due to lack of credible instruments. Hence, we treat the results as suggestive that part of the impact of these variables on migration works through the labor market.

As an example of the implied magnitudes, figure $3 \mathrm{a}$ presents the calculated elasticities with response to an increase in FDI by state for both the reduction in "push" or out migration from the state and increase in "pull" from the other states. Though in theory, the liquidity effect identified in the maquila and export cases could dominate and cause an increase in "push" migration, in the FDI case the coefficient is small and insignificant, and push is clearly reduced from all states with elasticities averaging .02. Pull elasticities are substantially higher averaging around .05 but reaching .1 in the case of Colima, Zacatecas and Campeche. A doubling of FDI in these states leads to a $10 \%$ increase in migrants attracted to the state and a $2 \%$ decline in outflows.

To see whether these magnitudes are important, figure $3 \mathrm{~b}$ calculates the impact of a $10 \%$ rise in each states' FDI on the magnitude of push and pull migration divided, as a measure of scale, by total out migration to both the US and other Mexican states. What is clear is that both effects are of non-trivial magnitude. The reduction in push migration lies between $1-3 \%$ of total migration while pull migration can range from under $.5 \%$ to again over $10 \%$ in the three states mentioned above. Inflows of FDI potentially have substantial impact as a mechanism for affecting migratory flows. 
Further, addressing Markusen and Zahniser's concern, it does not seem to be the case that the internal migrant population is so significantly distinct from that migrating to the US. Table 3 tabulates the educational attainment, age and gender of non-movers in Mexico and within Mexico migrants tabulated from the Mexican census, and that of recent migrants to the US as tabulated by the US census. ${ }^{8}$ Men have similar age profiles although women tend to be somewhat older when they migrate to the US, perhaps reflecting a delayed migration after their spouses. For both genders, however, what emerges is that, though not radically different, the domestic migrants are somewhat less educated than those internationally. Markusen and Zahniser's concern that FDI and trade would not prove a disincentive to migration because it did not affect the relevant migratory population seems unfounded.

\section{Simulations of US impact}

Ideally, we could use the estimates above to offer some guess at the magnitude of the impact on US migration. Clearly, for such an exercise to be relevant, it must be the case that the decision to migrate to the US, or alternatively, the types of people who decide to migrate to the US do not differ too much between the two destinations. As noted above, table 3 suggests that the demographics of the two groups are similar, and the literature is mixed although not necessarily inconsistent with this assumption. ${ }^{9}$ It does appear, however, that relative to men, women are more likely to migrate within Mexico, than to the US. This may reflect the strategy of households that migrate to the border to send the husband across to engage in the riskier and more intensive work while the wife

\footnotetext{
8 These findings are very similar to those of Chiquiar and Hanson (2003) using the US census.

9 Rivera-Batiz (1986) in an often cited article implicitly suggests that migrants' indifference between destinations: "The impact of the maquiladoras on migration to the United States is dependent on whether they are able to raise employment by more than they increase the labor supply in the border areas through induced migration from southern regions. If an excess supply of labor is generated at the border with surplus workers becoming either openly unemployed or underemployed, it is likely that there will be a spillover into illegal migration to the United States" (p. 265). The field work on "staged migration" can be read both ways. On the one hand, workers in the first stage, for instance, moving from Oaxaca to take jobs in Baja California have less information, contacts and coyote capital than when they decide to make a second stage crossing to the US. On the other hand, the underlying objective function of that individual is arguably the same and both migration costs (embodied in information or networks) and credit constraints are standard in the migration specifications. . See Durand and Massey (1992) for a review of the field literature on migration and Cornelius and Martin (1993) and Zabin and Hughes (1995)
} 
stays in the less risky, less demanding Mexican-side jobs that permit easier balancing of family responsibilities (Zabin and Hughes 1995). The literature does stress the importance of accumulated networking that appears to have caused some Mexican states to generate a disproportionate number of US bound migrants. To the degree possible, we controlled for such effects in the domestic regressions and, as detailed below, make additional adjustments in the simulations.

A second concern is whether the US variables are too "out of sample" to really treat the US as a " $33^{\text {rd }}$ Mexican State." In fact, as table 4 shows, the ratio of the per capita income of Mexico's richest state, the D.F. relative to its poorest is about 6.4 in nominal or 5.6 in real terms while the ratio of the average for the US relative to the D.F. is only about 1.9 or 1.5 PPP adjusted. That is, in terms of development the US is closer to Mexico City than Mexico City is to Chiapas. Nor are wage differentials radically different. The ratio of the Hispanic real wage in the US to the mean wage of the DF adjusted for PPP is roughly the same as the ratio of the real DF wage to that in Chiapas.

There may be some concern about the importance of the border representing fundamentally different "transport costs." In fact, the evidence is strong that this is more a difference in magnitude than kind. Donato, Durand and Massey (1992) argue that "our data from Mexico reveal a fairly high probability of apprehension by INS combined with a near-certain probability of ultimately entering the United States."(p 152) and that "every migrant who attempted a border crossing, whether apprehended or not, eventually gained entry" p 155 italics theirs. This suggests that border control serves more as a tariff than a quota.

The costs of movement are substant ially different, but perhaps not so much as we might think at first look. The present (2002) cost of a second class bus from Quintana Roo to Coahuila, one of the longer trips in our sample, was roughly \$US100 compared to very little between Mexico State and DF. ${ }^{10}$ Anecdotal evidence about the cost of direct transport across the border in the 1980s was \$150 (244 \$US 2002; Conover 1987 cited in

\footnotetext{
${ }^{10}$ White Star Bus line
} 
Hanson and Spilimbergo 1999), again, not so far out of sample. ${ }^{11}$ The cost of a Coyote or smuggler/guide appears to have held steady in real terms since the 1960s at around $\$ 350$ (\$2075 \$US2002; Donato, Durand and Massey 1992) ${ }^{12}$ although Crane et al (1990 cited in Hanson and Spillimbergo 1999) suggest that in 1993 only 8.3 percent of those apprehended by the INS had employed one.

Despite the differences that there are, the overall magnitudes of migration to the US vs to other states are not "too different." Of total migration, roughly $2 / 3$ is internal and $1 / 3$ is to the US. As a very crude first approximation, even if we make no adjustments for any likely covariates such as distance or relative wages, a simple ? ${ }^{2}$ statistic suggested by Bickenbach and Bode (2003) cannot reject that the same Markov process is driving both US and intra Mexican migration for 12 out of the 32 states. $^{13}$

To generate our "back of the envelope" calculations, we first note that total emigration from any state is the sum of migration to other states plus the US:

$$
\begin{aligned}
& M_{i}=\sum_{j=1}^{32} m_{i j}+m_{i U S} \text { for all } i=1, \ldots, 32 \\
& M_{i}=\sum_{j=1}^{32} \operatorname{Pop}_{i}{ }^{*} p_{i j}+m_{i U S}
\end{aligned}
$$

Total migration in Mexico is

$$
M=\sum_{i=1}^{32}\left(m_{i U S}+\operatorname{Pop}_{i} \sum_{j=1}^{32} p_{i j}\right)=M_{U S}+\sum_{i=1}^{32}\left(\operatorname{Pop}_{i} \sum_{j=1}^{32} p_{i j}\right)
$$

\footnotetext{
${ }^{11}$ Inflated from 1985 figure with CPI.

${ }^{12}$ This showed little change with the Immigration Reform and Control Act of 1986 suggesting that it is a fairly robust number. Figure was reached by inflating the 1960 figure by the CPI. Coyotes only get paid for successful crossings.

13 These results do rely on dropping Mexico state and the Federal district since they are effectively the same unit and have very high flows between them.
} 
where $M_{U S}$ is the total migration from Mexico to the US. From above, we know that the probability of migrating from state $\mathrm{i}$ to state $\mathrm{j}$ depends on the characteristics in $X, p_{i j}=\Phi(X \beta)$ and hence that $\Phi^{-1}\left(\hat{p}_{i j}\right)=z_{i j}=X b$. The percentage change in immigration to the US we can obtain as:

$$
\frac{\partial \ln M_{U S}}{\partial \ln X_{k}}=-\frac{1}{M_{U S}} \sum_{i=1}^{32} P_{O} p_{i} \sum_{k=1}^{32} \frac{\partial \Phi(X b)}{\partial \ln X_{k}}+\frac{1}{M_{U S}} \frac{\partial M}{\partial \ln X_{k}} \quad \text { for } k=\{i, j\}
$$

The first term of this elasticity captures the substitution effect--how much the existing flows of migrants will be reallocated among destinations given the change in $X_{k .}$. The second term captures the aggregate percentage change in total migration. This component we cannot capture from our domestic data. Given the liquidity effect detected earlier, it has the potential to be positive. However, the liquidity effect was non-significant in the FDI regressions and for no state did we find that out migration increased with respect to FDI. Thus, we consider the effects generated by the first term to offer a "lower bound" of the total effect on US migration.

The estimator used in the previous sector weighted all states equally beyond the necessary correction for heteroskedasticity brought on in the binomial context by differential state sizes (Domencich and McFadden, 1975). This is not necessarily the case when we want to estimate the function implicitly including the US as the $33^{\text {rd }}$ state:

$$
\hat{P}_{i j}=\Phi(X \hat{\beta}) \text { Subject to } \sum_{j=1}^{32+U S A} \hat{P}_{i j}=1
$$

Clearly, we lack the determinants of $\hat{P}_{i U S A}$, but we do have information on which states send more migrants to the US, particularly those with long established networks, which allows more precise estimation. The constraint can be easily rewritten as: $\frac{1}{1-\hat{P}_{i U S A}} * \sum_{j=1}^{32} \hat{P}_{i j}=1$ where the first term, a function of the share of each state that migrates 
to the US, becomes the weight of the estimated function. In practice, the estimates differed some, but not greatly from those previous.

Figure 4 presents the elasticity of migration to the US with respect to FDI above the axis and below the axis, the impact of an investment of \$US100 million on the number of people who migrate. The elasticities are quite low-- on average a doubling of FDI would lead only to a $1.5-2 \%$ reduction in migration. Further, for many states the impact of a single \$US100 million plant opening decreases migration little. However in some areas, such as Veracruz, where there is little FDI and a substantial amount of migration, the decline in outflows is substantialin the first case approaching 4,000 people. Again, these are intended as back of the envelope calculations that rely heavily on the

assumption that the US is considered broadly as the $32^{\text {rd }}$ destination for a migrant leaving his state. And again, we are only capturing the impact of redirection of existing migration to other Mexican states, not the overall decline in migration so these must be seen as lower bounds.

\section{Conclusions}

This paper evaluated the mechanisms through which NAFTA related variables might work to reduce migration to the US using data from within Mexico. We make three contributions to both the literature on migration more generally, and the impact of trade and FDI flows on migration.

First, we offer the first estimates of determinants of migration flows within Mexico and make some advances in the LDC migration literature. In line with recent innovations in the industrialized country literature, we generate proxies for both the level of amenities, costs of living and networks and generally find significance. Contrary to much of the literature, our specification generates intuitive and significant signs on home state labor market variables: a rise in home earnings or employment levels does deter migration. We argue that part of the traditional poor performance of the origin state variables is that they capture a mix of deterrent effects, and credit constraints. 
Second, we document that FDI, maquila value added, exports, and imports are substitutes for labor flows, appear to at least partly work through the labor market, and that the effects are of important magnitude. Further, though there is evidence that greater investment or trade may release credit constraints and increase migration as suggested by López and Schiff, in the case we examine, FDI, the effect does not dominate. Finally we generate some tentative inferences about the impact on Mexico-US migration treating the US implicitly as the $33^{\text {rd }}$ Mexican state. 


\section{References:}

Aroca, Patricio, Mariano Bosch and William F. Maloney. 2002. "Is NAFTA Polarizing México? or Existe También el Sur? Spatial Dimensions of Mexico's Post-Liberalization Growth." Mimeographed. Office of the Chief Economist for LCR, The World Bank

Barro, Robert J. and Xavier Sala-i-Martin. 1992. "Regional Growth and Migration: A Japan-United States Comparison." Journal of the Japanese and International Economies 6: $312-46$.

Ben-Akiva, M. and S.R. Lerman. 1985. Discrete Choice Analysis. Theory and Application to Travel Demand. MIT Press. Cambridge, MA, USA.

Beyer, H., P. Rojas and R. Vergara. 1999. "Trade Liberalization and Wage Inequality." Journal of Development Economics 59: 103-123.

Bickenbach, F. and E. Bode (2003) "Evaluating the Markov Property in Studies of Economic Convergence" International Regional Science Review 16:363-392

Borjas, George. 2001. "Does Immigration Grease the Wheels of the Labor Market?." Brooking Panel on Economics Activity, March 29-30.

Borjas, George. 1994. “The Economics of Immigration.” Journal of Economic Literature 32: 1667-717.

Cameron, Gavin, and John Muellbauer. 1998. "The Housing Market and Regional Commuting and Migration Choices." Discussion Paper 1945. Center for Economic Policy Research. London, UK.

Chiquiar, Daniel and Gordon H. Hanson. 2003. "International Migration, Self-Selection, and the Distribution of Wages: Evidence from Mexico and the United States." NBER working paper 9242. Cambridge, MA, USA.

Conover, Ted. 1987. Coyotes: A Journey through the Secret World of America's Illegal Aliens. Vintage New York, NY, USA.

Cornelius, Wayne A. and Philip L. Martin. 1993. "The Uncertain Connection: Free Trade and Rural Mexican Migration to the United States." International Migration Review.27(3): 484-512.

Crane, Keith, Beth J. Asch, Joanna Z. Heilbrunn, and Danielle C. Cullinane. 1990. "The Effect of Employer Sanctions on the Flow of Undocumented Immigrants to the United States." Urban Institute Report No. 90-8. Washington, DC, USA. 
Davila, Alberto and Rogelio Saenz. 1990. "The Effect of Maquiladora Employment on the Monthly Flow of Mexican Undocumented Immigration to the U.S., 1978-1982." International Migration Review 24(1): 96-107.

Davies, P.S., M.J. Greenwood and H. Li. 2001. "A Conditional Logit Approach to U.S. State-To-State Migration.” Journal of Regional Science 41(2): 337-360.

Domencich, T.A., and D. McFadden. 1975. Urban Travel Demand. A Behavioral Analysis. North Holland Publishing Co., NY, USA.

Donato, Katharine M., Jorge Druand and Douglas S. Massey. 1992. "Stemming the Tide? Assessing the Deterrent Effects of the Immigration Reform and Control Act." Demography 29: 139-157.

Durand, Jorge and Douglas S. Massey. 1992. "Mexican Migration to the United States: A Critical Review." Latin American Research Review 27(2): 3-42.

Esquivel, Gerardo Hernandez. 1997. "Essays on Convergence, Migration and Growth." Unpublished PhD. Dissertation. MIT, MA, USA.

Faini, R., J-M. Grether and J. De Melo. 1999. "Globalization, and migratory pressures from developing countries: a simulation analysis." In Faini, R., J. De Melo and K. F. Zimmermann, eds. Migration. The Controversies and the Evidence. Cambridge University Press, Cambridge, UK.

Faini, Riccardo (2004) "Trade Liberalization in a Globalizing World" mimeo, presented at the Annual Bank Conference on Development Economics.

Feenstra, R.C. and G.H. Hanson. 1995. "Foreign Direct Investment and Relative Wages: Evidence from Mexico's Maquiladoras." NBER working paper 5122. Cambridge, MA, USA.

Field, G.. 1982. "Place-to-Place Migration in Colombia." Economic Development and Cultural Change 31: 538-558.

Fry, T.R.L. and M.N. Harris (1998). "Testing for Independence of Irrelevant Alternatives. Some Empirical Results." Sociological Methods \& Research 26(3): 401423.

Gabriel, S.A., J. Shack-Marquez and W.L. Wascher. 1996. "Does Migration Arbitrage Regional Labor Market Differentials?" Regional Science and Urban Economics 23: 211233.

Goss, E. P and N.C. Schoening. 1984. "Search time, Unemployment and the Migration Decision.” Journal of Human Resources 19: 570-579. 
Gourieroux, Christian. 2000. Econometrics of Qualitative Dependent Variables. Cambridge University Press, Cambridge, UK.

Greenwood, M. J.. 1997. "Internal Migration in Developed Countries." In Rosenzweig and Stark Eds. Handbook of Families and Population Economics. North-Holland Publisher, Amsterdam. Holland.

Hanson, Gordon 2005. Globalization, Labor Income and Poverty in Mexico in Ann Harrison, ed., Globalization and Poverty, Chicago: University of Chicago Press and the National Bureau of Economic Research, forthcoming.

Hanson, Gordon. 1997. "Increasing Returns, Trade, and the Regional Structure of Wages." Economic Journal 107: 113-133.

Hanson, Gordon and Christopher Woodruff. 2003. "Emigration and Educational Attainment in Mexico." Mimeographed. University of California at San Diego, CA, USA.

Hanson, Gordon and Antonio Spillembergo. 1999. "Illegal Immigration, Border Enforcement, and Relative Wages: Evidence from Apprehensions at the U.S.-Mexico Border." American Economic Review 89: 1337-1357.

Herzog, H.W. Jr., A.M. Schlottmann and T.P. Boehm. 1993. "Migration as Spatial Job Search: A Survey of Empirical Findings." Regional Studies 27: 605-620.

Jones, Richard C. 2001. "Maquiladoras and U. S.-Bound Migration in Central Mexico." Growth and Change 32: 193-216.

Leonard, J.S. and R. McCulloch. 1991. "Foreign-Owned Businesses in the United State." In J.M. Abowd and R.B. Freeman, eds. Immigration, Trade and the Labor Market. NBER Project Report, The University of Chicago Press, IL, USA.

López and Schiff. 1998. "Migration and the Skill Composition of the Labour Force: The impact of Trade Liberalization in LDCs." The Canadian Journal of Economics, 31:318336.

Lucas, R.E.B. 1997. "Internal Migration in Developing Countries," In Rosenzweig and Stark, eds. Handbook of Families and Population Economics. North-Holland, Amsterdam.

Markusen, J.R. and S. Zahniser. 1999. "Liberalization and incentives for labor migration: theory with applications to NAFTA.” In R. Faini, J. De Melo and K.F. Zimmermann, eds. Migration. The Controversies and the Evidence. Cambridge University Press, Cambridge, UK. 
Markusen, J.R. and A.J. Venables. 1997. "The Role of the Multinational Firm in the Wage-Gap Debate." Review of International Economics 5: 435-51.

Massey, Douglas S. and Kristin E. Espinosa. 1997. "What's Driving Mexico-U.S. Migration? A theoretical, Empirical, and Policy Analysis." The American Journal of Sociology 102(4): 939-999.

McKenzie, David and Hillel Rapoport. 2004. "Network Effects and the Dynamics of Migration and Inequality: Theory and Evidence from Mexico." SCID working paper 201. Stanford, CA, USA.

Pagano, M.. 1990. "Discussion of Muellbauer and Murphy (1990) "Is the Balance of Payments Sustainable?" Economic Policy 5(2): 387-390.

Pudney, S.. 1989. Modeling Individual Choice. The Econometrics of Corners, Kinks and Holes. Basil Blackwell, Oxford, UK.

Rivera-Batiz, Francisco L.. 1986. "Can Border Industries Be a Substitute for Immigration?" The American Economic Review, Papers and Proceedings of the NinetyEight Annual Meeting of the American Economic Association 76(2): 263-268.

Roback, Jennifer. 1982. "Wages, Rents and the Quality of Life." Journal of Political Economy 6: 1257-1278.

Sjaastad, Larry A. 1962. "The Costs and Returns of Human Migration." Journal of Political Economy 70: 80-93.

Shultz, T.P.. 1982. "Lifetime Migration Within Educational Strata in Venezuela: Estimates of a Logistic Model." Economic Development and Cultural Change 31: 559593.

Spencer, P.D.. 1989. "Comments on Bover et al." Oxford Bulletin of Economics and Statistics 51: 153-157.

Stark, Oded, and J. Edward Taylor. 1991. "Migration Incentives, Migration Types: The Role of Relative Deprivation." The Economic Journal 101: 1163-1178.

Thomas, Alun. 1993. "The Influence of Wages and House Prices on British Interregional Migration Decisions." Applied Economics 25: 1261-1268.

Train, Kenneth. 1986. Qualitative Choice Analysis. Theory, Econometrics, and an Application to the Automobile Demand. The MIT Press, Cambridge, MA, USA.

Vanderkamp, J.. 1971. "Migration Flows, their Determinants and the Effects of Return Migration." Journal of Political Economy 79: 1012-1031. 
Zabin, Carol and Sallie Huges. 1995. "Economic Integration and Labor Flows: Stage Migration in Farm Labor Markets in Mexico and the United States.” International Migration Review 29(2): 395-422. 
Figure 1

\section{Net Migration 2000}
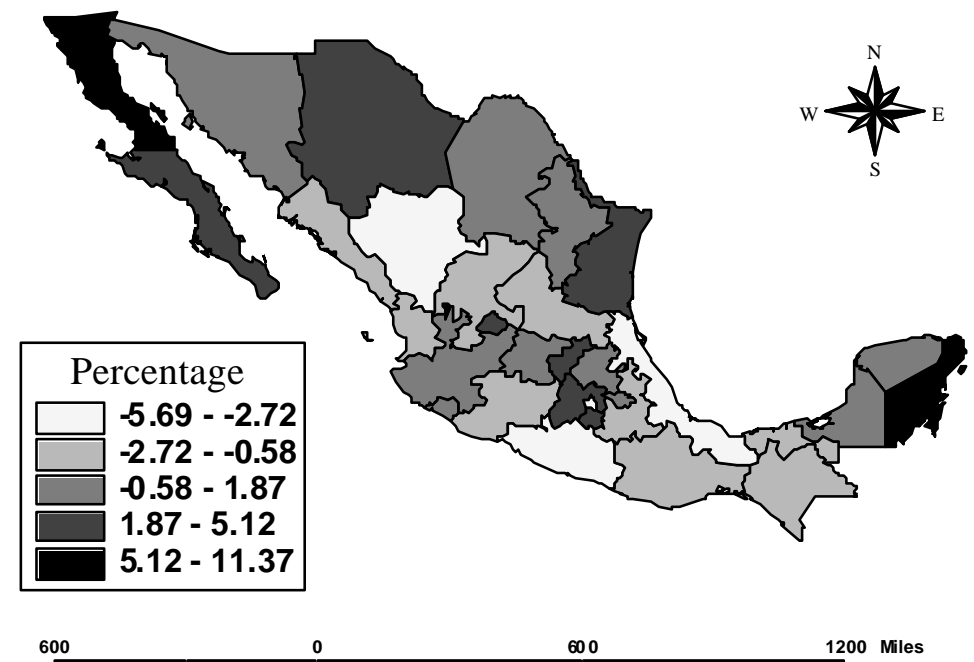

1200 Miles

Figure 2

\section{Per Capita FDI（From 1994 to 2000)}

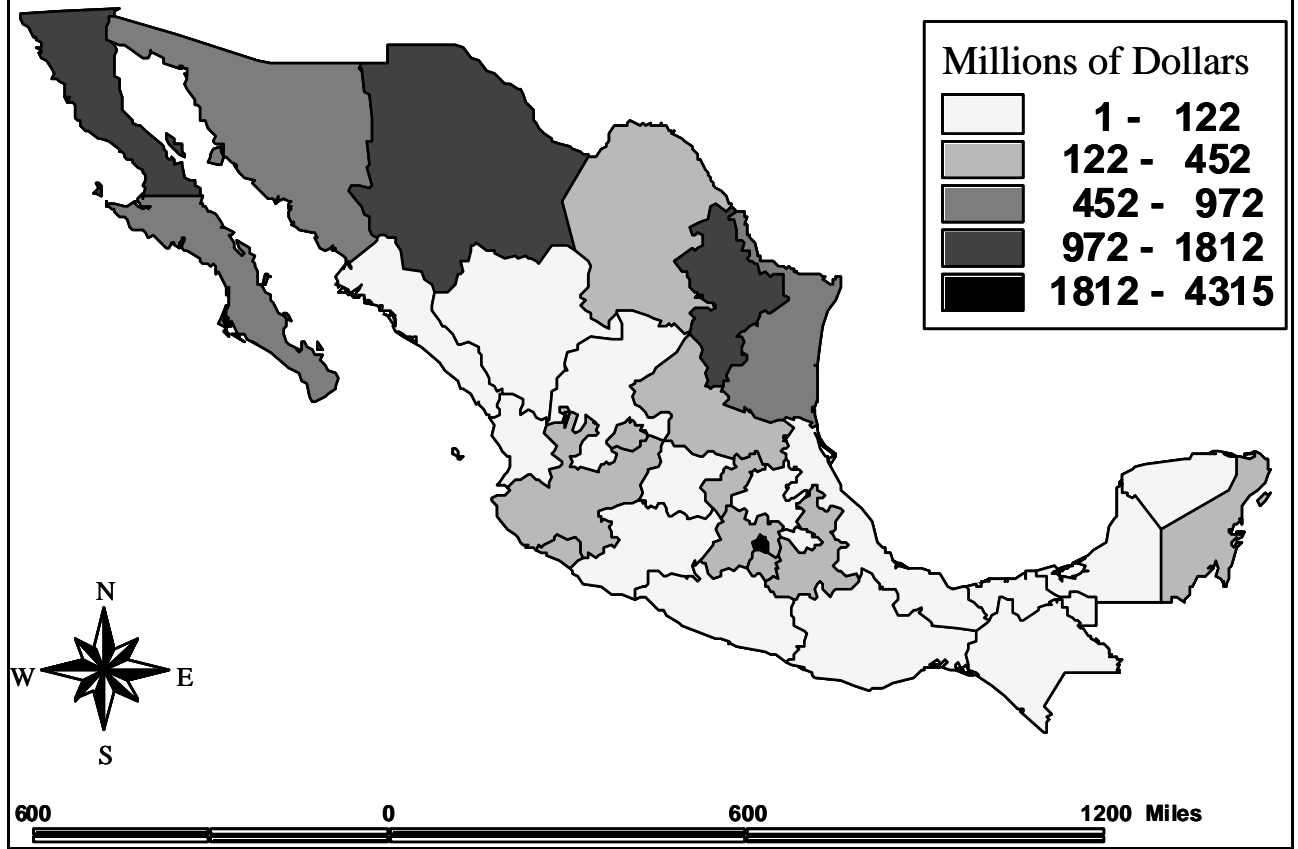


Figure 3a: Estimated Push and Pull Elasticities by State with respect to FDI

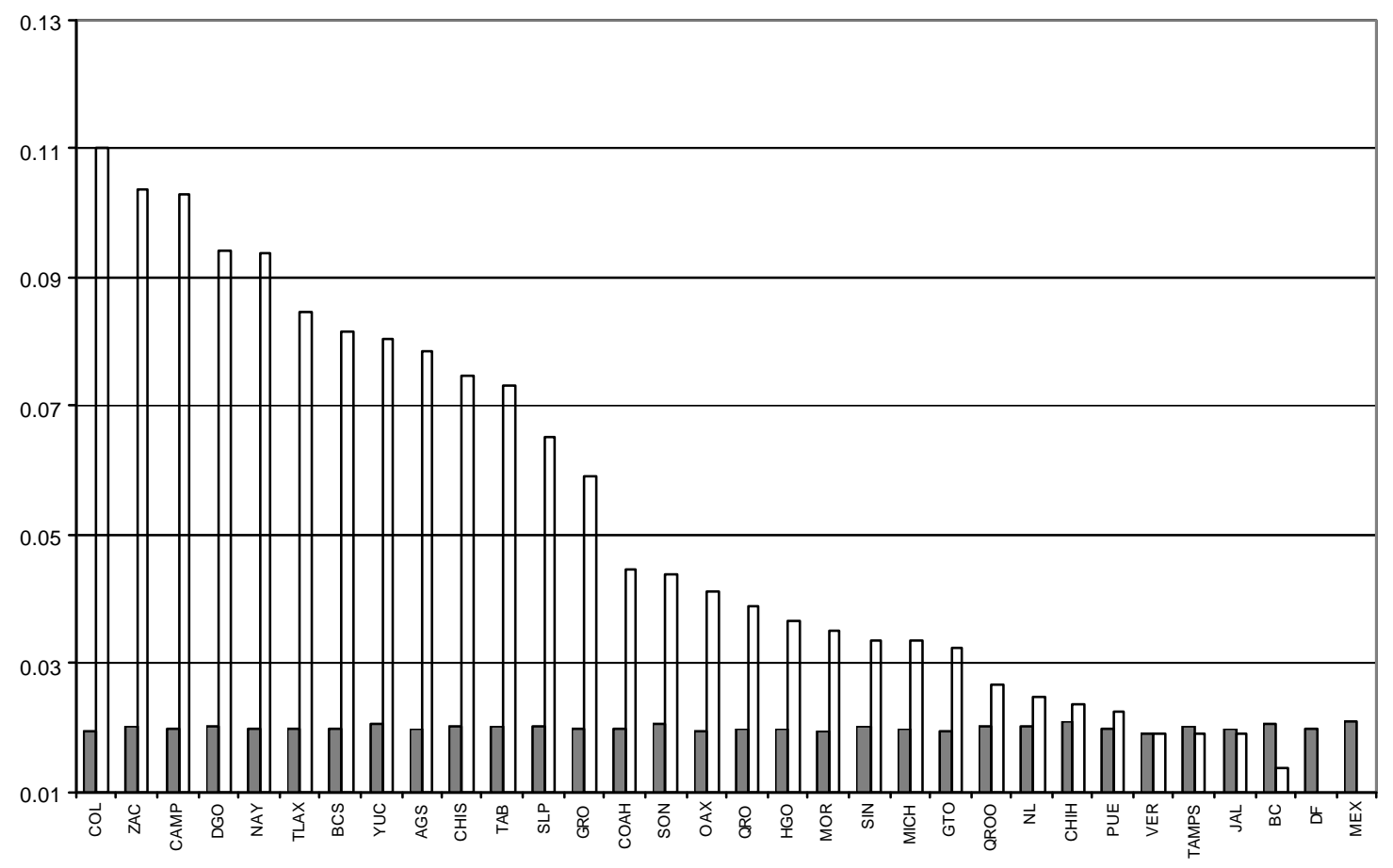

밀ij,xi|=Pushing

口 Epij,xj=Pulling

Figure 3b: Estimated Impact on Push and Pull Migration of a 10\% rise in FDI as a Share of Total Migration from State.

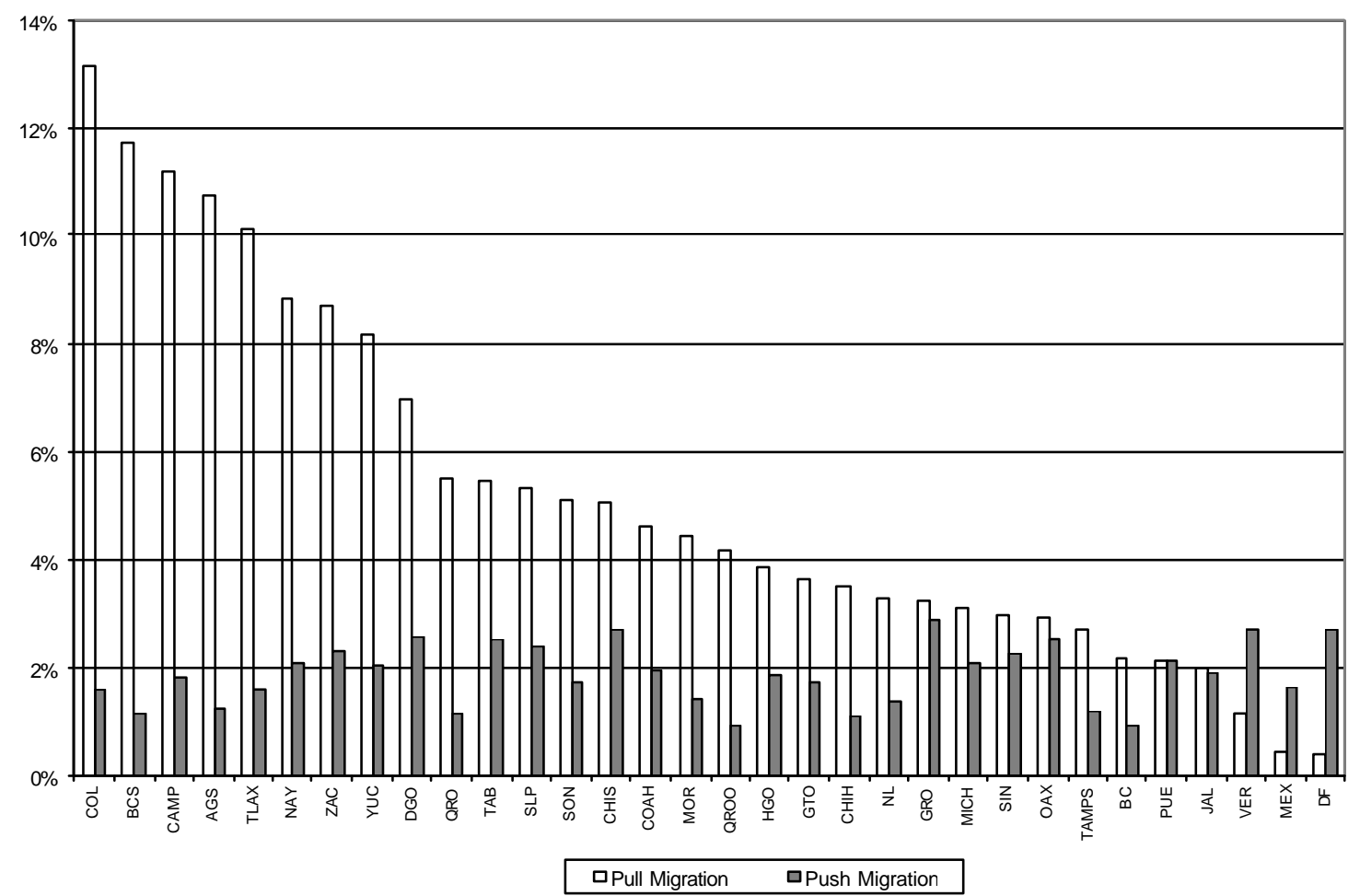


Figure 4: Elasticity Migration to US wrt FDI and Migration Response of a \$US100 Million Investment in State

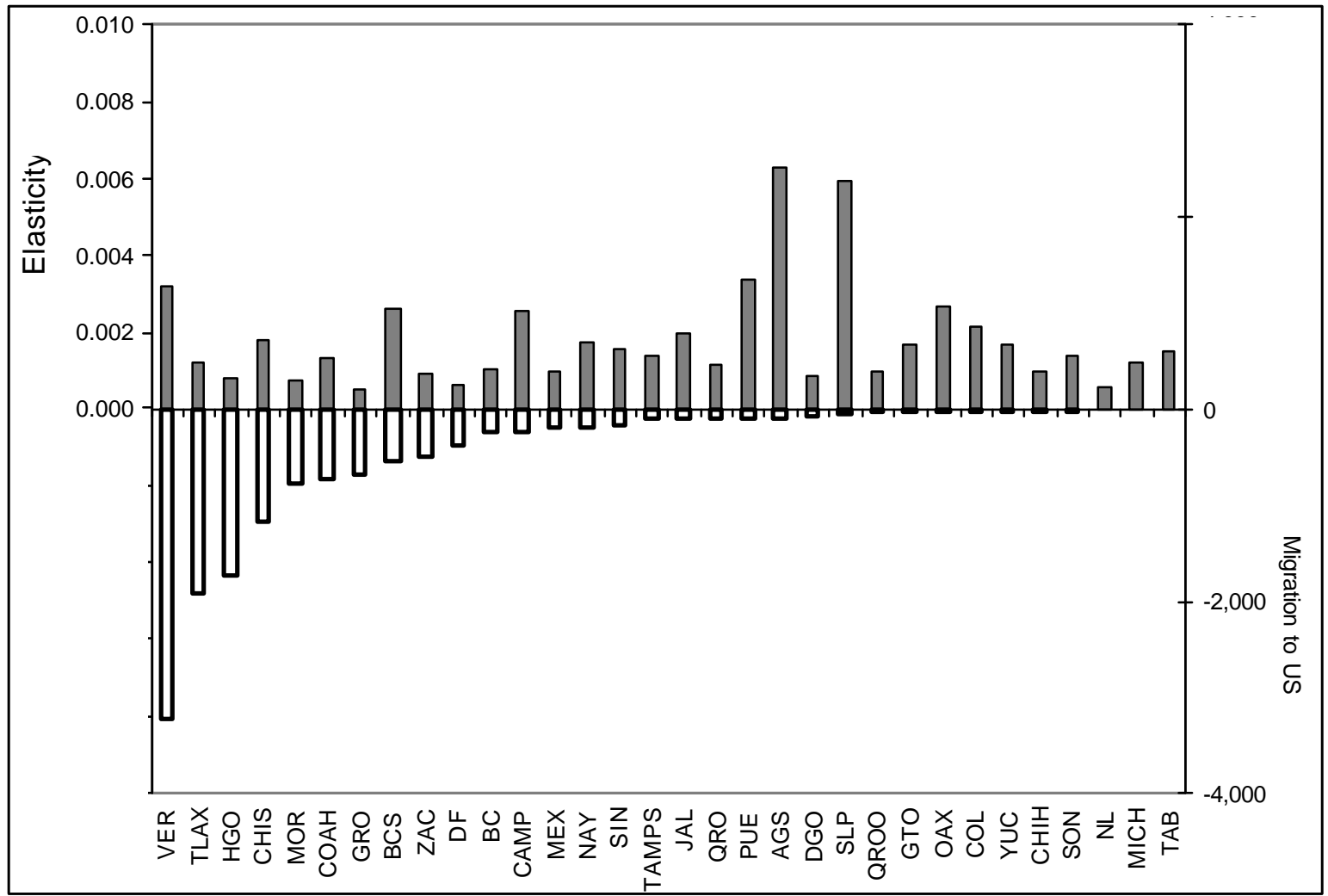


Table 1: Summary Statistics of Data

\begin{tabular}{|c|c|c|c|c|c|}
\hline & Obs. & Mean & St. Dev. & Min. & Max. \\
\hline Emigrants from $\mathrm{i}$ to $\mathrm{j}$ & 992 & 3,890 & 17,208 & 16 & 470,693 \\
\hline Population & 992 & $2,848,697$ & $2,440,552$ & 375,494 & $11,170,796$ \\
\hline Distance & 992 & 19.27 & 12.42 & 1 & 64.88 \\
\hline Distance sq. & 992 & 525.98 & 660.95 & 1.00 & 4209.00 \\
\hline Prices & 992 & 100.00 & 16.55 & 66.99 & 138.15 \\
\hline $\log$ Prices & 992 & 4.59 & 0.16 & 4.20 & 4.93 \\
\hline Unemployment & 992 & 2.99 & 1.04 & 1.46 & 6.64 \\
\hline Nominal wages & 992 & 1787 & 345 & 1208 & 3036 \\
\hline log Nominal wages & 992 & 7.47 & 0.18 & 7.07 & 8.01 \\
\hline Amenities & 992 & 2.11 & 1.00 & 0.10 & 4.72 \\
\hline FDI & 992 & 268.00 & 386.00 & 0.04 & 1617.00 \\
\hline $\log$ FDI & 992 & 4.35 & 2.15 & -3.11 & 7.38 \\
\hline Exports & 992 & 1452 & 2130 & 19.82 & 8578 \\
\hline log Exports & 992 & 6.14 & 1.69 & 2.98 & 9.05 \\
\hline Imports & 992 & 844 & 1219 & 5.52 & 4176 \\
\hline $\log$ Imports & 992 & 5.51 & 1.84 & 1.7084 & 8.33 \\
\hline Maquila & 306 & 97,681 & 129,480 & 1,029 & 453,211 \\
\hline $\log$ Maquila & 306 & 10.57 & 1.51 & 6.93 & 13.02 \\
\hline
\end{tabular}


Table 2: Determinants of Migration

\begin{tabular}{|c|c|c|c|c|c|c|c|c|c|c|}
\hline & \multirow{2}{*}{$\begin{array}{c}\text { Basic } \\
\text { 1a } \\
\end{array}$} & \multirow{2}{*}{$\begin{array}{c}\text { Reduced } \\
\text { sample } \\
1 \mathrm{~b} \\
\end{array}$} & \multicolumn{2}{|c|}{ FDI } & \multicolumn{2}{|c|}{$\begin{array}{c}\text { Maquila } \\
\text { (reduced sample) }\end{array}$} & \multicolumn{2}{|c|}{ Exports } & \multicolumn{2}{|c|}{ Imports } \\
\hline & & & $2 a$ & $2 b$ & $3 a$ & $3 b$ & $4 \mathrm{a}$ & $4 \mathrm{~b}$ & $5 \mathrm{a}$ & $5 \mathrm{~b}$ \\
\hline Distance & $\begin{array}{l}-0.039 \\
(15.61)\end{array}$ & $\begin{array}{l}-0.0553 \\
(10.38)\end{array}$ & $\begin{array}{l}-0.037 \\
(13.99)\end{array}$ & $\begin{array}{l}-0.0421 \\
(16.97)\end{array}$ & $\begin{array}{l}-0.0581 \\
(10.53)\end{array}$ & $\begin{array}{l}-0.0564 \\
(10.94)\end{array}$ & $\begin{array}{l}-0.0359 \\
(14.11)\end{array}$ & $\begin{array}{l}-0.0399 \\
(16.45)\end{array}$ & $\begin{array}{l}-0.0345 \\
(13.77)\end{array}$ & $\begin{array}{l}-0.0389 \\
(15.99)\end{array}$ \\
\hline Distance sq. & $\begin{array}{c}0.0005 \\
(8.92)\end{array}$ & $\begin{array}{l}0.0007 \\
(6.12)\end{array}$ & $\begin{array}{c}0.0005 \\
(9.04)\end{array}$ & $\begin{array}{r}0.0005 \\
(9.81)\end{array}$ & $\begin{array}{c}0.0008 \\
(6.85)\end{array}$ & $\begin{array}{c}0.0008 \\
(6.63)\end{array}$ & $\begin{array}{c}0.0005 \\
(8.49)\end{array}$ & $\begin{array}{l}0.0005 \\
(9.24)\end{array}$ & $\begin{array}{c}0.0004 \\
(8.30)\end{array}$ & $\begin{array}{r}0.0005 \\
(9.16)\end{array}$ \\
\hline Networks & $\begin{array}{c}0.004 \\
(12.58)\end{array}$ & $\begin{array}{c}0.0045 \\
(9.78)\end{array}$ & $\begin{array}{c}0.0034 \\
(9.64)\end{array}$ & $\begin{array}{l}0.0041 \\
(12.67)\end{array}$ & $\begin{array}{c}0.0042 \\
(8.68)\end{array}$ & $\begin{array}{c}0.0042 \\
(9.43)\end{array}$ & $\begin{array}{l}0.0037 \\
(11.12)\end{array}$ & $\begin{array}{l}0.0035 \\
(11.19)\end{array}$ & $\begin{array}{l}0.0041 \\
(12.55)\end{array}$ & $\begin{array}{l}0.0039 \\
(12.60)\end{array}$ \\
\hline Population i & $\begin{array}{c}-0.0014 \\
(0.33)\end{array}$ & $\begin{array}{c}-0.0175 \\
(2.08)\end{array}$ & $\begin{array}{c}0.0034 \\
(0.71)\end{array}$ & $\begin{array}{c}-0.0086 \\
(1.92)\end{array}$ & $\begin{array}{c}-0.0268 \\
(3.26)\end{array}$ & $\begin{array}{c}-0.0141 \\
(1.72)\end{array}$ & $\begin{array}{c}0.0055 \\
(1.24)\end{array}$ & $\begin{array}{c}0.0085 \\
(1.91)\end{array}$ & $\begin{array}{c}0.0087 \\
(1.96)\end{array}$ & $\begin{array}{c}0.0111 \\
(2.41)\end{array}$ \\
\hline Population $\mathrm{j}$ & $\begin{array}{c}0.0456 \\
(9.61)\end{array}$ & $\begin{array}{c}0.0286 \\
(3.12)\end{array}$ & $\begin{array}{c}0.0473 \\
(9.18)\end{array}$ & $\begin{array}{c}0.0384 \\
(7.95)\end{array}$ & $\begin{array}{c}0.0224 \\
(2.39)\end{array}$ & $\begin{array}{l}0.035 \\
(3.91)\end{array}$ & $\begin{array}{c}0.0415 \\
(8.41)\end{array}$ & $\begin{array}{l}0.0492 \\
(10.38)\end{array}$ & $\begin{array}{c}0.0366 \\
(7.55)\end{array}$ & $\begin{array}{r}0.0436 \\
(9.13)\end{array}$ \\
\hline Log. prices i & $\begin{array}{c}0.3079 \\
(3.45)\end{array}$ & $\begin{array}{c}0.0905 \\
(0.55)\end{array}$ & $\begin{array}{c}0.2764 \\
(3.21)\end{array}$ & $\begin{array}{c}0.3374 \\
(3.84)\end{array}$ & $\begin{array}{c}0.4605 \\
(3.67)\end{array}$ & $\begin{array}{l}-0.125 \\
(0.73)\end{array}$ & $\begin{array}{c}0.2079 \\
(2.65)\end{array}$ & $\begin{array}{c}0.1563 \\
(1.74)\end{array}$ & $\begin{array}{c}0.2356 \\
(3.05)\end{array}$ & $\begin{array}{r}0.1697 \\
(1.88)\end{array}$ \\
\hline Log. prices j & $\begin{array}{c}0.2843 \\
(3.71)\end{array}$ & $\begin{array}{c}0.1632 \\
(1.10)\end{array}$ & $\begin{array}{c}0.7152 \\
(9.89)\end{array}$ & $\begin{array}{c}0.2582 \\
(3.45)\end{array}$ & $\begin{array}{c}0.9122 \\
(7.95)\end{array}$ & $\begin{array}{c}0.1718 \\
(1.14)\end{array}$ & $\begin{array}{l}0.7792 \\
(11.68)\end{array}$ & $\begin{array}{c}0.3036 \\
(3.98)\end{array}$ & $\begin{array}{c}0.6542 \\
(9.72)\end{array}$ & $\begin{array}{c}0.3045 \\
(4.04)\end{array}$ \\
\hline Relative Amenities & $\begin{array}{l}0.003 \\
(1.47)\end{array}$ & $\begin{array}{c}-0.0277 \\
(0.93)\end{array}$ & $\begin{array}{c}0.0019 \\
(0.83)\end{array}$ & $\begin{array}{c}-0.0013 \\
(0.62)\end{array}$ & $\begin{array}{c}0.0038 \\
(0.13)\end{array}$ & $\begin{array}{c}-0.0096 \\
(0.33)\end{array}$ & $\begin{array}{c}-0.0005 \\
(0.24)\end{array}$ & $\begin{array}{c}-0.0029 \\
(1.38)\end{array}$ & $\begin{array}{c}0.0004 \\
(0.17)\end{array}$ & $\begin{array}{c}-0.0013 \\
(0.62)\end{array}$ \\
\hline Amenities i & $\begin{array}{c}0.0225 \\
(1.91)\end{array}$ & $\begin{array}{c}-0.0155 \\
(0.64)\end{array}$ & $\begin{array}{c}0.0471 \\
(4.04)\end{array}$ & $\begin{array}{r}0.0211 \\
(1.82)\end{array}$ & $\begin{array}{c}-0.0005 \\
(0.02)\end{array}$ & $\begin{array}{c}-0.0214 \\
(0.90)\end{array}$ & $\begin{array}{c}0.0459 \\
(3.82)\end{array}$ & $\begin{array}{c}0.0368 \\
(3.16)\end{array}$ & $\begin{array}{c}0.0654 \\
(5.15)\end{array}$ & $\begin{array}{c}0.0533 \\
(4.35)\end{array}$ \\
\hline \multicolumn{11}{|l|}{ Labor market } \\
\hline Relative unemp. & $\begin{array}{c}-0.1161 \\
(4.20)\end{array}$ & $\begin{array}{c}-0.1506 \\
(2.17)\end{array}$ & & $\begin{array}{c}-0.1391 \\
(5.12)\end{array}$ & & $\begin{array}{c}-0.1454 \\
(2.16)\end{array}$ & & $\begin{array}{c}-0.1097 \\
(4.10)\end{array}$ & & $\begin{array}{r}-0.1212 \\
(4.51)\end{array}$ \\
\hline Unemployment i & $\begin{array}{c}-0.0335 \\
(2.21)\end{array}$ & $\begin{array}{l}-0.134 \\
(3.10)\end{array}$ & & $\begin{array}{c}-0.0609 \\
(3.99)\end{array}$ & & $\begin{array}{l}-0.136 \\
(3.24)\end{array}$ & & $\begin{array}{c}-0.0322 \\
(2.21)\end{array}$ & & $\begin{array}{r}-0.0205 \\
(1.38)\end{array}$ \\
\hline Relative nominal wage & $\begin{array}{l}0.8025 \\
(12.46)\end{array}$ & $\begin{array}{l}1.0515 \\
(8.22)\end{array}$ & & $\begin{array}{l}0.8902 \\
(12.00)\end{array}$ & & $\begin{array}{c}0.8513 \\
(5.56)\end{array}$ & & $\begin{array}{c}0.753 \\
(10.02)\end{array}$ & & $\begin{array}{c}0.6188 \\
(7.65)\end{array}$ \\
\hline Log. nominal wage i & $\begin{array}{c}0.6903 \\
(6.72)\end{array}$ & $\begin{array}{l}1.2762 \\
(6.05)\end{array}$ & & $\begin{array}{l}1.044 \\
(8.98)\end{array}$ & & $\begin{array}{c}1.5221 \\
(6.08)\end{array}$ & & $\begin{array}{l}1.012 \\
(8.29)\end{array}$ & & $\begin{array}{l}0.899 \\
(7.02)\end{array}$ \\
\hline \multicolumn{11}{|l|}{ Investment and trade } \\
\hline $\begin{array}{l}\text { Relative }\{\text { FDI/Maquila } \\
\text { Imports }\}\end{array}$ & & & $\begin{array}{c}0.0291 \\
(6.40)\end{array}$ & $\begin{array}{c}-0.0091 \\
(1.81)\end{array}$ & $\begin{array}{c}0.0293 \\
(2.51)\end{array}$ & $\begin{array}{l}0.0535 \\
(4.00)\end{array}$ & $\begin{array}{l}0.0614 \\
(10.27)\end{array}$ & $\begin{array}{c}0.0195 \\
(2.88)\end{array}$ & $\begin{array}{l}0.0673 \\
(11.83)\end{array}$ & $\begin{array}{r}0.0309 \\
(4.40)\end{array}$ \\
\hline $\begin{array}{l}\text { Log }\{\mathrm{FDI} / \text { Maquila/ Exp } \\
\text { /Imports\}i }\end{array}$ & & & $\begin{array}{c}0.0085 \\
(1.36)\end{array}$ & $\begin{array}{c}-0.0407 \\
(5.78)\end{array}$ & $\begin{array}{r}0.0447 \\
(2.51)\end{array}$ & $\begin{array}{c}-0.0236 \\
(1.17)\end{array}$ & $\begin{array}{c}0.0136 \\
(1.50)\end{array}$ & $\begin{array}{c}-0.0458 \\
(4.31)\end{array}$ & $\begin{array}{c}0.0174 \\
(1.96)\end{array}$ & $\begin{array}{l}-0.033 \\
(3.02)\end{array}$ \\
\hline DF and Mexico State & $\begin{array}{c}-0.2147 \\
(5.26)\end{array}$ & $\begin{array}{c}0.0119 \\
(0.16)\end{array}$ & $\begin{array}{l}-0.266 \\
(6.02)\end{array}$ & $\begin{array}{c}-0.1219 \\
(2.85)\end{array}$ & $\begin{array}{r}-0.099 \\
(1.29)\end{array}$ & $\begin{array}{c}-0.0247 \\
(0.33)\end{array}$ & $\begin{array}{c}-0.2531 \\
(6.05)\end{array}$ & $\begin{array}{c}-0.2558 \\
(6.39)\end{array}$ & $\begin{array}{c}-0.2664 \\
(6.54)\end{array}$ & $\begin{array}{r}-0.2382 \\
(6.03)\end{array}$ \\
\hline Constant & $\begin{array}{c}-10.3586 \\
(13.94)\end{array}$ & $\begin{array}{c}-12.6053 \\
(9.56)\end{array}$ & $\begin{array}{l}-7.3816 \\
(14.23)\end{array}$ & $\begin{array}{c}-12.6744 \\
(15.64)\end{array}$ & $\begin{array}{l}-9.0691 \\
(11.73)\end{array}$ & $\begin{array}{c}-13.2986 \\
(9.86)\end{array}$ & $\begin{array}{l}-7.4026 \\
(14.94)\end{array}$ & $\begin{array}{c}-11.9351 \\
(15.31)\end{array}$ & $\begin{array}{l}-7.0175 \\
(14.45)\end{array}$ & $\begin{array}{l}-11.315 \\
(13.83)\end{array}$ \\
\hline Observations & 992 & 306 & 992 & 992 & 306 & 306 & 992 & 992 & 992 & 992 \\
\hline R-squared & 0.7 & 0.84 & 0.66 & 0.72 & 0.83 & 0.85 & 0.68 & 0.72 & 0.69 & 0.72 \\
\hline
\end{tabular}

Estimates: Least squares weighted by group (gprobit). "i" and " $j$ ” are origin and destination states respectively. 1a presents the base regression for all states and $1 \mathrm{~b}$ presents the results with a reduced sample of states with data on maquila value added. Columns $2 \mathrm{a}, 3 \mathrm{a}, 4 \mathrm{a}$ and $5 \mathrm{a}$ present the results without labor market variables, but including FDI, maquila value added, exports, and imports respectively. The amenities, labor, and investment and trade variables are included as a relative measure $(\log \mathrm{Xj}$ ” $-\log \mathrm{Xi})$ and a free standing value at the origin, $\log \mathrm{Xi}$. Columns $2 \mathrm{~b}, 3 \mathrm{~b}, 3 \mathrm{~b}$, and $5 \mathrm{~b}$ add the labor market variables. Imports and FDI statistics were provided by the Central Bank of Mexico. The Maquilas Value Added is based on Banco de Datos division of the INEGI statistics (http://dgcnesyp.inegi.gob.mx/bdine/bancos.htm). Exports was provided by the Ministry of Finance (Hacienda).

Absolute value of $\mathrm{t}$-statistics in parentheses 
Table 3: Migration Patterns by Education and Age

\begin{tabular}{lccc|ccc|ccc}
\hline & \multicolumn{3}{c|}{ Males } & \multicolumn{3}{c|}{ Females } & \multicolumn{3}{c}{ Total } \\
\cline { 2 - 10 } & $\begin{array}{c}\text { Stayers in } \\
\text { Mexico }\end{array}$ & $\begin{array}{c}\text { Movers } \\
\text { within } \\
\text { Mexico }\end{array}$ & $\begin{array}{c}\text { Recent } \\
\text { migrants } \\
\text { to the US }\end{array}$ & $\begin{array}{c}\text { Stayers in } \\
\text { Mexico }\end{array}$ & $\begin{array}{c}\text { Movers } \\
\text { within } \\
\text { Mexico }\end{array}$ & $\begin{array}{c}\text { Recent } \\
\text { migrants } \\
\text { to the US }\end{array}$ & $\begin{array}{c}\text { Stayers in } \\
\text { Mexico }\end{array}$ & $\begin{array}{c}\text { Movers } \\
\text { within } \\
\text { Mexico }\end{array}$ & $\begin{array}{c}\text { Recent } \\
\text { migrants } \\
\text { to the US }\end{array}$ \\
\hline Schooling (\%) & & & & & & & & & \\
No schooling & 14.1 & 10.5 & 8.0 & 16.0 & 11.0 & 9.6 & 15.1 & 10.7 & 8.6 \\
1 to 4 & 27.9 & 19.7 & 5.3 & 26.8 & 19.5 & 5.6 & 27.3 & 19.6 & 5.4 \\
5 to 8 & 28.9 & 25.5 & 32.1 & 29.2 & 28.2 & 29.6 & 29.1 & 26.9 & 31.1 \\
9 & 12.9 & 16.4 & 12.4 & 12.3 & 16.6 & 11.3 & 12.6 & 16.5 & 11.9 \\
10 to 11 & 4.0 & 5.1 & 7.3 & 3.9 & 5.2 & 6.2 & 3.9 & 5.1 & 6.9 \\
less than 12 & 87.8 & 77.2 & 65.1 & 88.2 & 80.5 & 62.2 & 88.0 & 78.9 & 64.0 \\
12 & 5.2 & 8.7 & 24.6 & 6.0 & 9.5 & 24.8 & 5.6 & 9.1 & 24.7 \\
13 to 15 & 2.4 & 4.2 & 6.1 & 2.4 & 3.7 & 7.4 & 2.4 & 3.9 & 6.6 \\
more than 15 & 4.6 & 9.9 & 4.2 & 3.4 & 6.3 & 5.6 & 4.0 & 8.0 & 4.7 \\
Age & 31.2 & 28.6 & 28.3 & 32.2 & 27.8 & 30.7 & 31.7 & 28.2 & 29.2 \\
N & $4,008,334$ & 159,712 & 694,206 & $4,288,508$ & 172,192 & 461,990 & $8,296,842$ & 331,904 & $1,156,196$ \\
\hline
\end{tabular}

Source: For migrants to the US, the 2000 US Census and within Mexico, the 2000 Mexican Census. 
Table 4: Monthly wages and GDP per capita, Mexico and United States

\begin{tabular}{l|l|l}
\hline Mexico & US \\
Current \$us $\begin{array}{c}\text { PPP adjusted by } \\
\text { State CPI }\end{array}$ & Current \$us \\
\hline
\end{tabular}

\section{$\underline{\text { GDP per capita }}$}

$\begin{array}{lccc}\text { Average } & 5,393 & 8,349 & 29,451 \\ \text { Min. } & 2,368 & 3,617 & 20,856 \\ \text { Max. } & 15,226 & 20,268 & 40,870 \\ \text { Max./Min. } & 6.4 & 5.6 & 2.0 \\ \text { Average US/Max. Mexico } & 1.9 & 1.5 & \end{array}$

Monthly wage

\begin{tabular}{|c|c|c|c|}
\hline Average & 372 & 575 & 1,716 \\
\hline Min. & 218 & 375 & \\
\hline Max. & 551 & 825 & \\
\hline Max./Min. & 2.5 & 2.2 & \\
\hline Average US/Max. Mexico & 3.1 & 2.1 & \\
\hline
\end{tabular}

Notes (1) INEGI; (2) Author's estimation for male urban workers using ENEU (3) Bureau of Economic Analysis (http://www.bea.doc.gov); (4) Bureau of Labor Statistics (http://www.bls.gov/cps/cpsaat37.pdf) median earnings of Hispanic origin workers. 